\title{
Statyba
}

\section{THE INFLUENCE OF SUDDEN INCREASE IN TEMPERATURE AND HUMIDITY ON STRESS- STRAIN STATES IN EXTERIOR FINISHING LAYERS OF MULTILEAF WALLS WITH FLEXIBLE TIES}

\section{G. Marčiukaitis}

To cite this article: G. Marčiukaitis (1998) THE INFLUENCE OF SUDDEN INCREASE IN TEMPERATURE AND HUMIDITY ON STRESS-STRAIN STATES IN EXTERIOR FINISHING LAYERS OF MULTILEAF WALLS WITH FLEXIBLE TIES, Statyba, 4:3, 219-226, DOI: 10.1080/13921525.1998.10531408

To link to this article: https://doi.org/10.1080/13921525.1998.10531408

Submit your article to this journal $[\pi$

Џ Article views: 62 


\section{THE INFLUENCE OF SUDDEN INCREASE IN TEMPERATURE AND HUMIDITY ON STRESS-STRAIN STATES IN EXTERIOR FINISHING LAYERS OF MULTILEAF WALLS WITH FLEXIBLE TIES}

\section{G. Marčiukaitis}

\section{Introduction}

Every building structure with thermoinsulating layers should meet requirements not only of thermal resistance but also those of strength, stability, crack, frost-resistance, etc.

Analysis of multilayered structures is complicated. Many methods are proposed which differ in accuracy of results and their analysis indicate that strength and crack resistance calculations of multileaf walls should be performed with allowance for stiffness of layers, ties between them and also for their purpose and location in the structure, strain compatibility of layers.

According to standard documentation and other proposals $[1,2]$, crack resistance analysis of exterior layers is performed for the case when all layers are rigidly joined and only external loads are taken into account. There are indications that compatibility of material deformations should be observed. But there is no instructions how it can be achieved and how to evaluate temperature-humidity actions which can change suddenly.

Investigations and practice indicate that finishing layers of exterior side often crack, eg, render, glued cladding material, thin layer of painting spall off together with thin layer of plaster and sometimes the whole layer of render cracks and spall off. It makes not only worse the aesthetic appearance of building facades but also decreases the durability of exterior layers and thermal resistance of wall. But there are almost no proposals for theoretical evaluation of such phenomena and practical analysis of actions caused by them.

\section{Stress-strain states of multileaf walls with flexible ties}

In most cases layers of the interior face of a building wall take the greatest loads. Exterior layers of outer side in general support dead weight and resist wind forces. The main structural diagrams of multileaf walls with flexible ties and finishing layers are shown in Fig 1. Finishing layers, of course, can be of sheet products able to deform freely.
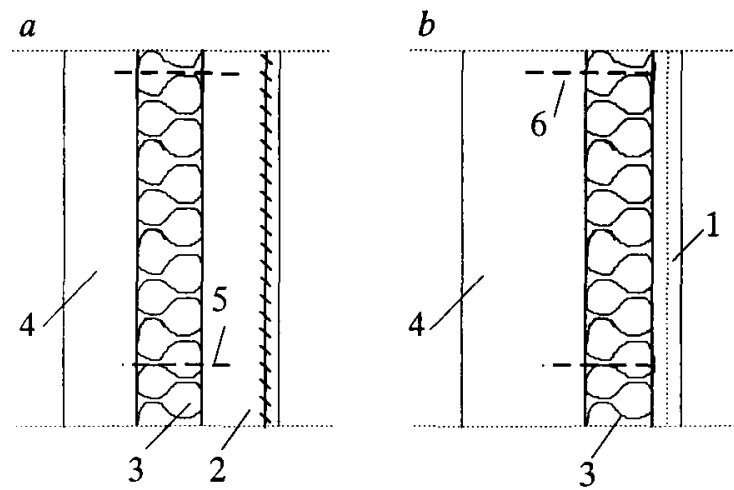

Fig 1. Diagrams of wall structures with flexible ties: 1 - exterior finishing layer; 2 - rigid exterior layer; 3 - thermoinsulating leaf; 4 - interior bearing leaf; 5 - flexible ties; 6 - fastening of damp proof layer

In many cases the external finishing layer (1) acts together with adjacent rigid layer (2) or with soft thermoinsulating layer (3). In addition, finishing leaves from 2-3 layers are used, properties of which are different. The diagram in Fig 1 is applicable and for single-leaf (solid) wall from rigid materials (bricks, block, etc.). The difference is such that stress from vertical loads will be distributed in layers (1). 
Almost always the properties of external finishing layer (1) differ from those of the layer with which it is bonded.

Various investigations and recommendations [ 3 , 4] as well as our observations show that wall surface in summer (June-August months) can be warmed from direct sun action up to $60{ }^{\circ} \mathrm{C}$ during several hours. Besides, their humidity increases due to rain.

Because of change in humidity, positive temperature and radiation of sun external layers expand. But their free expansion is restricted by rigid layer in which temperature and humidity do not get at once. Temperature distribution and its character in separate layers depend on many factors: mechanical-physical properties of materials, thickness of layers, humidity, etc. Distribution of mean values of temperature and humidity in the external layer is shown in Fig 2. a)

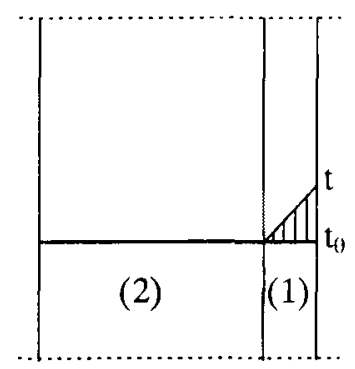

b)

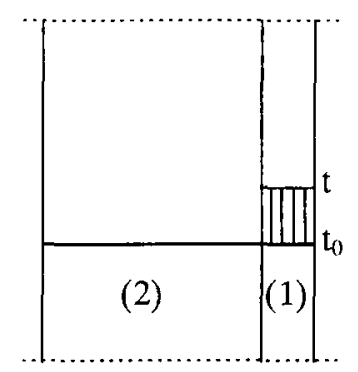

Fig 2. Diagrams of distribution of average values of temperature and humidity in the exterior layer: $a$-non-uniform distribution; $b$ - uniform

It can be seen in Fig 2 that two cases of distribution of mean temperature and humidity at their sudden increase are assumed.

Case 1: temperature and humidity in the external (finishing) layer vary lineal along its thickness (Fig 2, diagram a). Their values at interfaces of layers are equal. Such conditions may occur in the case when temperature and humidity suddenly (in several hours) increase.

Case 2: similar to the first one but temperature and humidity in the external layer are distributed uniformly (Fig $1 \mathrm{~b}$ ). This can occur when warm air wave comes together with rain, and the internal layer is less receptive to temperature and humidity.

Our investigations and analysis of defects of the external layers of walls have shown that when an external covered finishing layer (render) is covered by paint which is absorbed into its surface then the finishing layer obtains different properties in respect of its thickness and cracks by exfoliation. Such situation is substantiated by investigations of finishing layers from foliated render [5]. It may be explained in such way that due to paint absorption a layer of 2-3 mm thickness is formed with coefficient of expansion due to temperature change substantially different from that of the layer without absorbed paint.

Different deformations of layers due to temperature and humidity create shear stress at interfaces of layers. Free deformation of layers of greater expansion is restrained by layers of lower deformation. In layers of greater expansion and in those of lower-tension forces, compression forces appear.

When shear and compression forces due to different deformations develop, the external finishing layer does not crack at the same time but it often buckles spalling off from the adjacent layer and then crack or may be crushed.

In addition, the possibility of spalling off and buckling is increased by wind suction and possible penetration of vapour (humidity) from interval layers to outside. If the paint cover does not allow humidity to escape to outside then it facilitates to spall off that cover together with the layer of plaster into which the paint is absorbed. General mechanics of failure of the external layer due to sudden change of humidity and temperature is shown in Fig 3. Similar results were also obtained by other authors [5,6]. Distribution and directions of action show that the external layer is subjected to compression and bending. If the bond between layers deteriorate due to shear and other actions (for example, technological failures) [7] then layers spall off from each other or layers with absorbed paint become blistered.

\section{Determination of expansion deformation of materi- als of layers due to temperature and humidity}

Data on free deformations of materials due to temperature and humidity are necessary for determining forces in separate wall layers when temperature and humidity change. It is to be stressed, that there are almost no data on temperature and humidity deformations of separate structure of materials which form these members or composites of materials $[8,9]$. For 


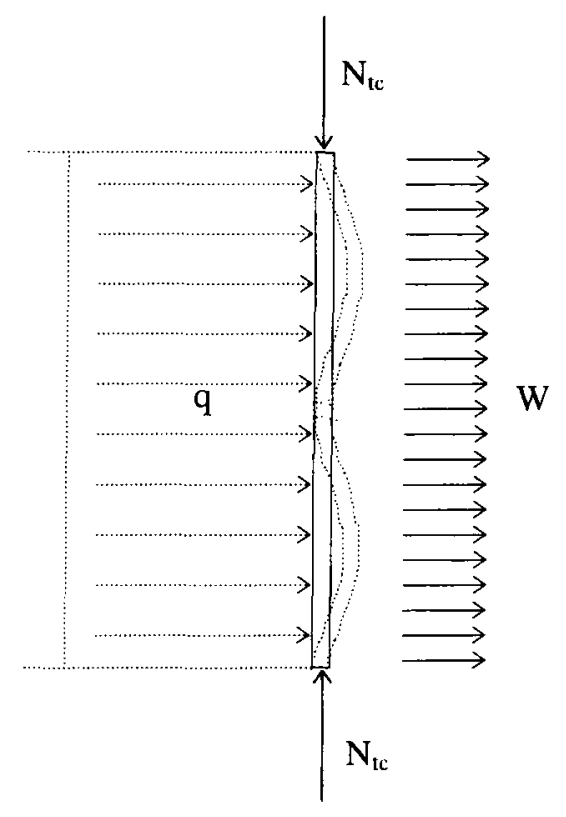

Fig 3. Actions on the exterior finishing layer and failure diagrams: $N_{t, c}$ - compression due to increase in temperature and humidity; $q$ - vapour pressure; $W$ - wind suction

example, for ceramic bricks - $\alpha=(4,5-5,0) \cdot 10^{-6}$, cement mortar $-13,6 \cdot 10^{-6}$; sand - $(11,0-11,8) \cdot 10^{-6}$; gravel $10,8 \cdot 10^{-6}$; limestone $-9,1 \cdot 10^{-6}$; granite crushed stone $7,4 \cdot 10^{-6}$, etc. These numbers indicate temperature expansion coefficients for main components of mortar and do not differ substantially. But temperature expansion coefficient for ceramic bricks is about twice less than these for materials making mortar.

When expansion coefficients of separate components $\alpha_{\mathrm{i}}$ are known using the "mixing" law $[9,10]$, it is possible to calculate temperature expansion coefficient $\alpha_{c}$ for a composite (mortar, masonry) by the following formula:

$$
\alpha_{c}=\alpha_{1} \cdot V_{1}+\alpha_{2} V_{2}+\ldots+\alpha_{n} V_{n}=\sum_{i=1}^{n} \alpha_{i} V_{i}
$$

where $\alpha_{i}$ is temperature expansion coefficient of any component forming a composite (render, masonry),

$V_{i}$ is relative volume of respective component $\left(V_{1}+V_{2}+\ldots+V_{\mathrm{n}}=1\right)$.

Since the composition of mortar is selected according to the ratio of masses of constituents, then, the mass of constituent $m_{i}$ and density $\rho_{i}$ being known, the volume parts of constituents will be:

for the first $V_{1}=\frac{m_{1} / \rho_{1}}{m_{1} / \rho_{1}+m_{2} / \rho_{2}+\ldots+m_{n} / \rho_{n}}$ for the second $V_{2}=\frac{m_{2} / \rho_{2}}{m_{1} / \rho_{1}+m_{2} / \rho_{2}+\ldots+m_{n} / \rho_{n}}$, etc.

Adapting formula (1) and presenting data on the temperature expansion coefficients for separate constituent parts of render (plaster), one obtains that the coefficient of temperature expansion for the most widely used compositions of cement:lime:sand plasters are equal to $(10,5-12,6) \cdot 10^{-6}$ and it is close to the known experimental data $[2,8,9]$. But there is almost no data on temperature expansion coefficient plaster layers which include absorbed paint and also on plasters made with polymer admixtures. The performed analysis [11] indicates that temperature expansion coefficients of polymers and also that of polymer paint film are $(50-90) \cdot 10^{-6}$, ie nearly $5-8$ times greater than these for cement mortar.

Analysis of temperature expansion coefficients for plasters with various constituents according to formula (1) was made. Fig 4 shows that the coefficient of temperature expansion for layer of plaster with polymers or with absorbed paint increases together with value of temperature expansion coefficient of constituent with greater expansion and with relative volume of this constituent. These data indicate that if temperature expansion coefficient of polymers is 7 times greater than that for a plaster then 5\% addition of polymer admixtures results in almost 1,3 times increase of temperature expansion coefficient.

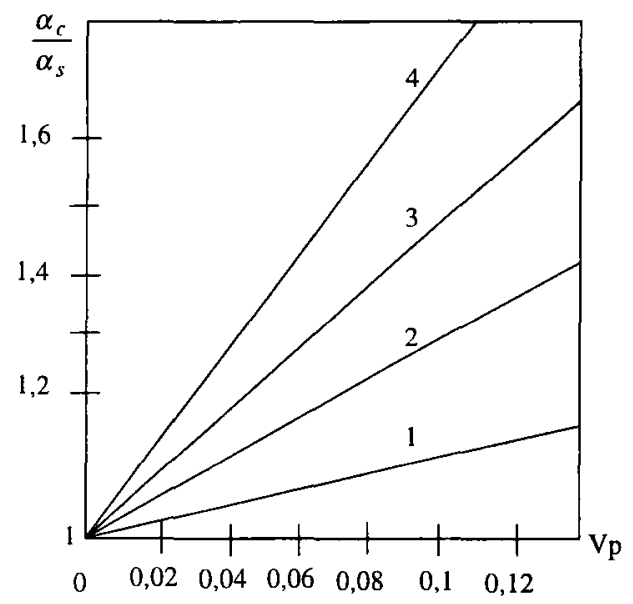

Fig 4. Relationship between temperature expansion coefficient of composite leaf and ratio of temperature expansion coefficients of components: $1-\left(\frac{\alpha_{p}}{\alpha_{s}}\right)=2 ; 2-4 ; 3-6 ; 4-8$ and of volume ratio of polymer (paints) 
Observations and investigations of existing buildings show that $15-30 \%$ of paint volume is absorbed in 2-3 mm deep layer. It means that temperature expansion coefficient of this layer will be over twice greater than that of plaster layer without absorbed paint. It indicates that even at the same change in temperature shear stress will appear at the interface of these layers and also tension and compression stresses in layers themselves.

As it was mentioned, the external layer may be suddenly moistened by rain. Not always finishing (paint) protects it from soaking. It may be permeable to humidity or humidity may pass through various micro- and macrocracks that have formed due to technological defects or shrinkage [7]. But there are very little data on expansion of plasters of various composition during their moistening. It is possible to point to works by Prof V.Stankevičius and his disciples. Since render mortar according to its constituents is very similar to concrete, then with allowance for expansion mechanics and effect it is possible to use data on expansion of concrete during its wetting $[8,12,13,14]$. It is usually assumed that the expansion coefficient due to humidity is analogous to temperature expansion coefficient $\alpha$. On the other hand, expansion due to humidity coefficient $\eta$ is a relative weight during wetting by liquid. These, similarly as in the determination of temperature deformations, expansion deformations due to humidity will be:

$$
\varepsilon_{s w}=\eta\left(U-U_{0}\right),
$$

where $U$ - humidity after rain; $U_{0}$ - united humidity (before rain).

According to design codes, dimensions for values by formula (2) are assumed as follows: $\eta-\frac{\mathrm{mm} / \mathrm{mm}}{\mathrm{g} / \mathrm{g}}$; $U, U_{0}-\mathrm{g} / \mathrm{g}$. For concrete $\eta=5 \cdot 10^{-3} \frac{\mathrm{mm} / \mathrm{mm}}{\mathrm{g} / \mathrm{g}}$. But for fine-grained concrete (mortar) this coefficient is substantially greater. In practical calculations of cementsand concrete, it is recommended to take $\eta$ value 1,2 times greater. When complex (cement-lime-sand) mortar is used, its expansion will be less and for practical calculations it is reasonable to take $\eta=4,5 \cdot 10^{-3}$ $\frac{\mathrm{mm} / \mathrm{mm}}{\mathrm{g} / \mathrm{g}}$.

\section{Determination of stress in layers at sudden increase in temperature and humidity}

In calculation of forces and stresses at sudden increase of temperature and humidity, it possible to assume that all layers behave elastically.

For analysis, unit width strips of two layers of wall are taken with expansion coefficients $\alpha_{1}$ and $\alpha_{2}, \eta_{1}$ and $\eta_{2}$, elasticity modulus of materials $E_{1}$ and $E_{2}$ (Fig 5). Considering a case (Fig 2) of distribution of temperature and humidity in respect to thickness of layers, we assume that the initial temperature in layers is distributed uniformly, but its increase in layers 1 varies linearly.

Since $\alpha_{1}>\alpha_{2}$ and $t_{1}>t_{2}$, the external layer expanding more tends to sag towards outside. At the same time it will also bend the other layer with which it is bonded. Assuming that there are no other external actions, we can forces acting in each layer by axial force $N_{1}\left(N_{2}\right)$ and moment $M_{1}\left(M_{2}\right)$ [15, 16]. These forces should be in equilibrium, ie:

$$
\begin{gathered}
N_{1}-N_{2}=0 ; \quad N_{1}=N_{2}=N, \\
N\left(\frac{\delta_{2}+\delta_{1}}{2}\right)=M_{1}+M_{2} .
\end{gathered}
$$

a)

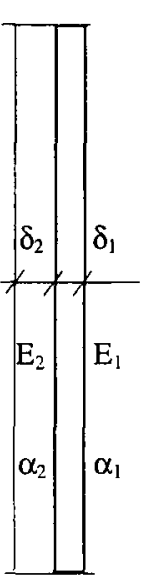

c)
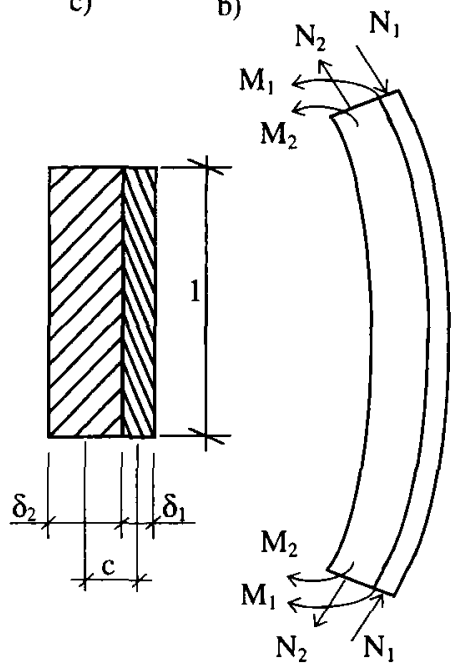

Fig 5. Diagram for calculation of general deformation of layers: $\mathrm{a}$ - when temperature and humidity are constant; $\mathrm{b}$ after increase in temperature and humidity; c - diagram of horizontal section of layers 
Unknowns of the equation $N$ and $M$ and relationship between stresses in both layers can be found from conditions, that both layers deflect equally, ie $1 / \rho_{1}=1 / \rho_{2}$ and at the interface of layers deformations are the same.

Layers 2 will deflect only due to moment, because humidity and temperature are distributed along the depth uniformly, ie

$$
\frac{1}{\rho_{2}}=\frac{M_{2}}{E_{2} I_{2}} .
$$

Layer in which there is a gradient of temperature and humidity will tend to deflect in respect to their difference $[8,17]$, ie,

$$
\frac{1}{\rho_{t}}=\frac{0,5\left(\alpha_{1} \Delta t+\eta \Delta U_{1}\right)}{\delta_{1}} .
$$

Then curvature of the layer 1 will be:

$$
\frac{1}{\rho_{1}}=\frac{M_{1}}{E_{1} I_{1}}+\frac{\left(\alpha_{1} \Delta t+\eta \Delta U_{1}\right)}{\delta_{1}} .
$$

From equations (5) and (7) we obtain

$$
M_{2}=\frac{1}{\rho_{2}} E_{2} I_{2}
$$

and

$$
M_{1}=\frac{1}{\rho_{1}} E_{1} I_{1}-\frac{0,5\left(\alpha_{1} \Delta t+\eta \Delta U_{1}\right) E_{1} I_{1}}{\delta_{1}} .
$$

Allowing for $\frac{1}{\rho_{1}}=\frac{1}{\rho_{2}}=\frac{1}{\rho}$ and using conditions (5), (7) and (8) it is possible to write equation (4) as follows:

$$
\begin{aligned}
& N\left(\frac{\delta_{1}+\delta_{2}}{2}\right)=\frac{1}{\rho} E_{1} I_{1}+\frac{1}{\rho} E_{2} I_{2}- \\
& -\frac{0,5\left(\alpha_{1} \Delta t+\eta \Delta U_{1}\right) E_{1} I_{1}}{\delta_{1}} .
\end{aligned}
$$

Making notations:

$$
\begin{gathered}
E_{1} \delta_{1}=B_{1} ; \quad E_{2} \delta_{2}=B_{2} ; \quad E_{1} I_{1}=D_{1} ; \\
E_{1} I_{1}+E_{2} I_{2}=D \\
\alpha_{1} \Delta t+\eta \Delta U_{1}=\Theta_{1},
\end{gathered}
$$

from equation (8) we obtain:

$$
N=\frac{2 D}{\rho\left(\delta_{1}+\delta_{2}\right)}-\frac{\Theta_{1} D_{1}}{\delta_{1}\left(\delta_{1}+\delta_{2}\right)} .
$$

Axial forces and moments are needed for determining stresses and deformations. On the other hand, conditions (8) and (11) indicate that they can be determined when the curvature is known.

Since actions acting on layers are in equilibrium, the hypothesis of plain sections being valid and layers acting jointly, the deformations of layers at their interfaces should be equal.

In general case deformations due to separate actions are calculated according to such known formulae: due to axial forces

$$
\varepsilon_{N}=\frac{N_{i}}{E_{i} \delta_{i} b},
$$

due to moment or when curvature is known

$$
\varepsilon_{\rho}=\frac{\delta_{i}}{2 \rho},
$$

and due to increase of temperature and humidity

$$
\varepsilon_{0}=\alpha_{i} \Delta t_{i}+\eta_{1} \Delta U_{i}=\Theta_{i} .
$$

Applying assumptions theory of elasticity $[15,16]$ and general conditions of equilibrium, we can write down such an equation: deformations due to actions acting on one and another layers at their interface are equal. Using expressions (12), (13) and (14) and taking into account that there is no change of temperature and humidity in the layer 2 , we write down this equation in such a way:

$$
\Theta_{1}-\frac{N_{1}}{E_{1} \delta_{1}}-\frac{\delta_{1}}{2 \rho}=\frac{N_{2}}{E_{2} \delta_{2}}+\frac{\delta_{2}}{2 \rho} .
$$

Since $N_{1}=N_{2}$, then using condition (9) and notation (10), equation (15) can be written as follows:

$$
\begin{aligned}
& \Theta_{1}-\left[\frac{2 D}{\rho\left(\delta_{1}+\delta_{2}\right)}-\frac{2 \Theta_{1} \cdot D_{1}}{\delta_{1}\left(\delta_{1}+\delta_{2}\right)}\right]\left(\frac{1}{B_{1}}+\frac{1}{B_{2}}\right)= \\
& =\frac{1}{2 \rho}\left(\delta_{1}+\delta_{2}\right) .
\end{aligned}
$$

Formula for calculation of curvature can be obtained from equation (16) after some rearrangements:

$$
\begin{aligned}
& \frac{1}{\rho}=\Theta_{1}\left[1+\frac{2 D_{1}}{\delta_{1}\left(\delta_{1}+\delta_{2}\right)}\left(\frac{1}{B_{1}}+\frac{1}{B_{2}}\right)\right] \times \\
& \times\left[\frac{\delta_{1}+\delta_{2}}{2}+\frac{2 D}{\delta_{1}+\delta_{2}}\left(\frac{1}{B_{1}}+\frac{1}{B_{2}}\right)\right]^{-1} .
\end{aligned}
$$


When axial forces and curvature are known, and using a well-known strength of materials formulas, the stress at any point of layers may be calculated:

$$
\sigma_{i}=\frac{N_{i}}{b \delta_{i}} \pm \frac{E_{i} z_{i}}{b \rho},
$$

where $i=1,2$ (notation of layers); $z_{i}$ - distance point in layer stress at which is calculated from centre of gravity, b - width of section in consideration.

In the second case, when temperature in layers is distributed uniformly (Fig 2 b), there will be no deflection due to non-uniform temperature and humidity distribution in the external layer. Then condition (8) will be such:

$$
M_{1}=\frac{1}{\rho} E_{1} I_{1} \text { and } M_{2}=\frac{1}{\rho} E_{2} I_{2} .
$$

Condition (8) for determining axial forces will become of such shape:

$$
N=\frac{2 D}{\rho\left(\delta_{1}+\delta_{2}\right)} .
$$

Curvature is determined similarly as for the case 1. For its calculation the following formula is obtained on the basis of the same conditions and assumptions:

$$
\frac{1}{\rho}=\Theta_{1}\left[\frac{\delta_{1}+\delta_{2}}{2}+\frac{2 D}{\delta_{1}+\delta_{2}}\left(\frac{1}{B_{1}}+\frac{1}{B_{2}}\right)\right]^{-1} \text {. }
$$

When axial forces and curvatures are obtained stresses can be calculated by formula (18).

\section{Stress state analysis}

When temperature and humidity distribution gradient in the external layer is sudden, there is not enough time for full development of plastic deformations and their influence on redistribution and change of stresses is not great. Therefore stress state investigation and comparison in elastic stage give sufficiently accurate results. Calculations and diagrams presented in Fig 5 indicate that stress value is influenced by ratios of thickness of layers $\left(\delta_{1} / \delta_{2}\right)$ and by their elasticity modulus.

$$
\text { Analysis of influence of ratio } n=\frac{E_{1}}{E_{2}} \text { or } E_{1}=n E_{2}
$$
on variation shows that the difference between stresses in sides of the external layer decreases together with the ratio of layers. For example, at $\delta_{1} / \delta_{2}=0,05$ stresses at the external layer side and at the interface with the other layer are almost equal (Fig 6, curves 5). When this ratio increases, ie the thicker external layer, the greater difference of stresses. As curves 1 and 2 in Fig 6 indicate, tension stress occurs in the side plane of the external layer, when $\delta_{1} / \delta_{2}>0,3$ and $n>1,5$.

Increase in values of these parameters leads to the increase of stress and their values may become greater than the tension strength of finishing materials. Such ratio of parameters of external finishing layer may become when they are made from layers of different materials.

Similar character of stress development is also in the second case. Curves in Fig 7 indicate that together with the increase of modulus of elasticity of finishing (external) layer stress at its interface plane with the other layer also increase.

Calculation indicates, that up to $\delta_{1} / \delta_{2}=0,4$ stresses at both sides of the external layer due to elasticity (stiffness) do not accrue. Distribution shape of compression stresses in respect of layer thickness is that of trapezium. Greater stresses are at the interface of layers (curves in Fig 6) and smaller at outer surface plane.

Stresses due to a sudden increase of temperature and humidity are added to stresses from other actions and danger of cracking and even failure may increase to the external layer. On the other hand, the presented

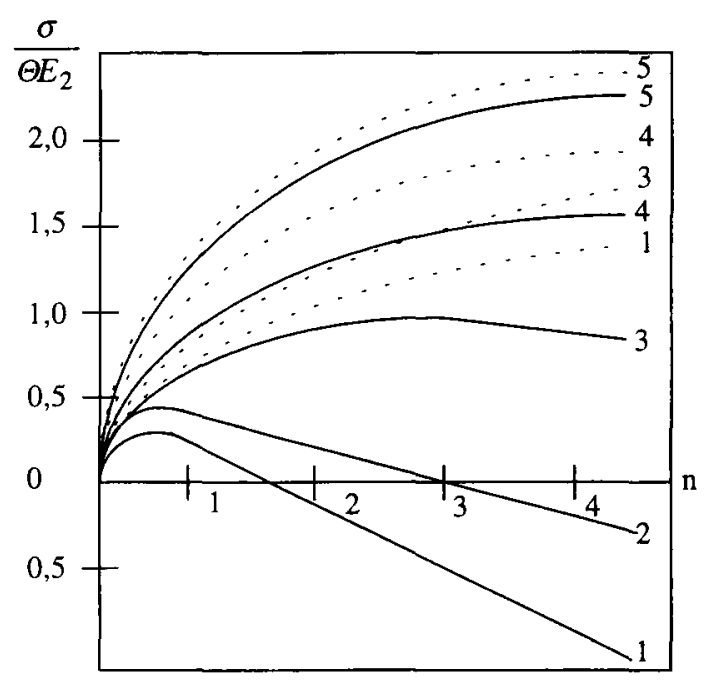

Fig 6. Relationship between stresses in layer and ratios of modulus (n) and thickness $\left(\left(\delta_{1} / \delta_{2}\right): 1-\delta_{1} / \delta_{2}=0,4 ; 2-0,3\right.$; $3-0,15 ; 4-0,1 ; 5-0,05$. Solid curve - for exterior surface, dotted - for interface with another layer 


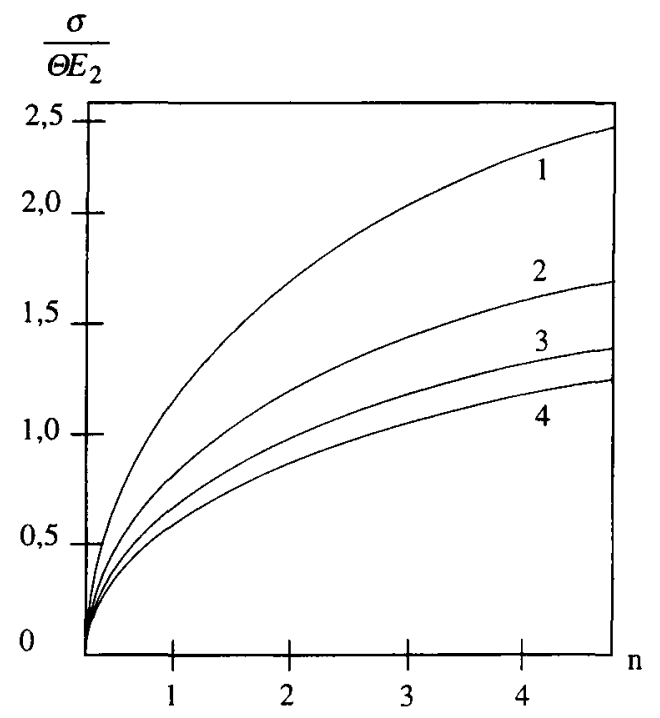

Fig .7. Relationship between stresses when temperature and humidity in the finishing layer is distributed uniformly and ratios of modulus of elasticity $\left(n=E_{1} / E_{2}\right)$ of layers and their thickness $\left(\delta_{1} / \delta_{2}\right)$. Numbers of curves mean: 1 $\delta_{1} / \delta_{2}=0,05 ; 2-0,10 ; 3-0,15 ; 4-0,20$.

method for determining stress due to sudden increase of temperature and humidity indicates that selection of deformation properties for materials of layers, as well as their ratios of thickness enable to regulate stresses in layers and at the same time to reduce possibilities for external layer buckling or spalling off when additional actions occur, ie to reduce critical stresses for the external (finishing) layer.

\section{Conclusions}

The carried out investigations and calculation have shown that sudden increase in temperature and humidity may cause stress in a layer facilitating buckling or spalling off this layer or its part from adjacent layer. The proposed method enables to determine this stress and to select such thickness of layers and properties of their materials that this stress would be as small as possible. When this stress is decreased possibility to occur for general critical. Stress in the external layer decreases. Application of this method enables to determine stress in separate layers of finishing leaf when they are made of materials with different properties. Since for practical calculation there is a lack of data on expansion of materials of the external (finishing) layer due to temperature and humidity, proposals for determination of these deformations are presented.

\section{References}

1. Каменные и армокаменные конструкции. СНиП II-22-81. М.: Стройиздат. $66 \mathrm{c.}$

2. A. I. Hendry. Structural Masonry. London. Macmillan Education. Ltd. 1990, 282 p.

3. Рекомендации по расчету конструкций крупнопанельньх зданий на температурно-влажностные воздействия. М.: Стройиздат, 1983. $136 \mathrm{c}$.

4. А. К. Гончаров. Исследование влияния ориентации здания на механическое состояние каменной облицовки // Сб. научных трудов ЦНИИСК им. В.А.Кучеренко "Исследование крупнопанельных и каменных конструкций”. Москва, 1984, с. 98-108.

5. J. Ramanauskas. Sienų šiluminès izoliacijos išorinio apdailinio sluoksnio atsparumas klimato poveikiams. Disertacijos autoreferatas. Kaunas: Technologija, 1997. $25 \mathrm{p}$.

6. V. Stankevičius. Pastatų atitvaru drègminè būsena ir atsparumas šalčiui. Kaunas: Technologija, 1997. 142 p.

7. G.Marčiukaitis. Technologiniu faktoriu itaka sluoksniuotujų sieny išorinių sluoksnių supleišejimui // 5-osios tarptautines konferencijos "Naujos statybinès medžiagos, konstrukcijos ir technologijos", ivykusios Vilniuje 1997 m. gegužès 21-24 d., straipsniai. 4 t. Vilnius: Technika, 1997, p. 172-177.

8. С. В. Александровский. Расчет бетонных и железобетонных конструкций на температурные и влажностные воздействия (с учетом ползучести). М.: Стройиздат, 1973. $442 \mathrm{c}$.

9. Concrete Structures Euro-Design Handbook. Editor J.Eibl. Berlin, 1995. 755 p.

10. G. Marčiukaitis. Statybiniu kompozitų kūrimo ir savybių prognozavimo principai. Vilnius: Technika, 1998. $134 \mathrm{p}$.

11. Г. Марчюкайтис. Исследование физико-механических свойств бетона и железобетона, пропитанных полимерами, и учет их особенностей при расчете конструкций. Дис. ... габил. док-ра, Витьнюс-Москва, 1979. $407 \mathrm{c}$.

12. С. В. Александровский. О набухании бетона при его увлажнении // Бетон и железобетон, 10, 1959, c. 5-9.

13. Р. Лермит. Проблемы технологии бетона. М.: Стройиздат, 1959. $292 \mathrm{c}$.

14. R. Miniotaitè. Pastatu sienu išorinių apsauginiu apdailos sluoksniu ir dangų ilgaamžiškumas // Respublikines konferencijos "Statyba ir architektūra" pranešimai. Kaunas, 1998, p. 248-254.

15. Н. И. Безухов. Основы теории упругости, пластичности и ползучести. М.: Высшая школа, 1961. $536 \mathrm{c}$.

16. С. П. Тимошенко. Устойчивость стержней, пластин и оболочек. М.: Наука, 1971. 807 с.

17. А. Ф. Милованов. Расчет жаростойқих железобетонньх конструкший. М.: Стройиздат, 1975. 231 с.

İteikta 19980715 
STAIGAUS TEMPERATŪROS IR DRÉGMĖS PADIDE்JIMO IৃTAKA SLUOKSNIUOTŲJU SIENU SU LANKSČIAIS RYŠIAIS IŠORINIŲ APDAILOS SLUOKSNIU ITEMPIỤ IR DEFORMACIJUৃ BŪVIUI

\section{G. Marčiukaitis}

\section{S a n t r a u k a}

Sluoksniuotuju sienu išorinių sluoksnių, kurie ne tik apsaugo termoizoliacinius sluoksnius nuo ivvairiy poveikiy, bet ir turi architektūrinę bei estetinę paskirtị, supleišèjimas yra neleistinas. Atlikti tyrimai ir apskaičiavimai parodé, kad staigus temperatūros ir drégmès padidejjimas gali sukelti sluoksnyje ittempius, pagreitinančius šio sluoksnio ar jo dalies atplyšimą nuo gretimo sluoksnio ir sumažina atsparumą šalčiui. İtempių dydis ir ju pasiskirstymo išoriniame sluoksnyje būdas priklauso nuo deformaciju modulių $\left(n=E_{1} / E_{2}\right)$ ir sluoksnių storiu $\left(\delta_{l} / \delta_{2}\right)$ santykių. Šiems santykiams didejjant, sluoksnio išoriniame krašte gali atsirasti tempimo įtempiai, viršijantys ribines sluoksnio medžiagos tempimo stiprio reikšmes. Toks išorinių apdailos sluoksnių nurodytų parametrų santykis gali būti ir tuomet, kai jie daromi sluoksniuoti ir iš skirtingų savybių medžiagų. Pasiūlyta metodika leidžia nustatyti šiuos įtempius ir parinkti tokius sluoksnių storius ir jų medžiagų savybes, kad ịtempiai būtu kuo mažesni. Juos sumažinus sumažeja tikimybe atsirasti bendriesiems kritiniams ịtempiams išoriniame sluoksnyje. Pagal šią metodiką galima nustatyti ịtempius atskiruose apdailos sluoksnio sluoksneliuose, jeigu jie yra sudaryti iš medžiagu, turinčiu skirtingas savybes. Kadangi praktiniam apskaičiavimui trūksta duomenụ apie išorinių (apdailos) sluoksnių medžiagu plètimąsi nuo temperatūros ir drègmès, todèl pateikti pasiūlymai šioms deformacijoms nustatyti.

Gediminas MARČIUKAITIS. Professor, Doctor Habil. Department of Reinforced Concrete Structures. Vilnius Gediminas Technical University (VGTU), Sauletekio al. 11, 2040 Vilnius, Lithuania.

A graduate of Civil Engineering Faculty of Kaunas Polytechnic Institute (1957). PhD (1963). Research visit to the University of Illinois (1969). Doctor Habil thesis (1980) at Moscow Civil Engineering Institute. Professor (1982). Author and co-author of 4 monographs, 2 text-books and more than 250 scientific articles. Research interests: mechanics of reinforced concrete, masonry and layered structures, new composite materials, structures and investigation and renovation of buildings. 